\title{
UPAYA MENINGKATKAN HASIL BELAJAR SISWA PADA MASA PANDEMI COVID-19 DENGAN MICROSOFT KAIZALA UNTUK MATERI PELUANG
}

\author{
SUSI AMALIA \\ Pascasarjana PMIPA, Universitas Indraprasta PGRI, Jakarta \\ e-mail: amaliasusi1@gmail.com
}

\begin{abstract}
ABSTRAK
Kemajuan teknologi menjadikan hidup kita lebih mudah. Perkembangan teknologi juga membawa hal baru dalam dunia pendidikan yang dapat dimanfaatkan salah satunya untuk metode dan media pembelajaran. Pandemi Covid-19 menyisakan berbagai permasalahan pada dunia pendidikan. Sebagian besar siswa telah kehilangan kesempatan belajar, mendapatkan kesulitan belajar bahkan minat belajar karena pembelajaran tidak lagi dapat dilaksanakan secara langsung. Penerapan pembelajaran berbasis teknologi dan internet secara daring (dalam jaringan) yaitu serangkaian interkoneksi antara teknologi yang saling berhubungan satu dan lainnya atau bisa disebut komunikasi melalui jaringan internet secara sinkron maupun asinkron bisa dijadikan alternatif pelaksanaan pembelajaran pada masa pandemi Covid-19. Kaizala termasuk ke dalam media pembelajaran yang memanfaatkan dua jenis komunikasi ini yaitu media sinkron dan asinkron. Pada penelitian kali ini penulis menitikberatkan pada peningkatan hasil belajar dengan memanfaatkan teknologi. Kaizala merupakan media pembelajaran online yang berbasis platform sosial media yang ringan untuk diikuti seperti media sosial whatsapp namun memiliki keunggulan sehingga dipakai dalam pembelajaran karena memiliki banyak fitur penunjang yang sesuai untuk pembelajaran. Penulis melakukan Penelitian Tindakan Kelas (PTK) sebagai upaya untuk meningkatkan hasil belajar pada masa pandemi Covid 19 dengan menggunakan Microsoft Kaizala. Berdasarkan hasil temuan pada siklus I dan siklus II pada uraian diatas ternyata dengan menerapkan media pembelajaran microsoft kaizala dengan memanfaatkan sarana teknologi yang ada pada siswa kelas XII Akuntansi 3 dapat meningkatkan hasil belajar siswa untuk materi Peluang
\end{abstract}

Kata Kunci: hasil belajar, pandemi Covid-19, microsoft kaizala

\section{ABSTRACT}

Advances in technology have made our life easier. Technological developments also bring new things in the education that can be used, one of them is for learning methods and learning media. The Covid-19 pandemic has made various problems in education. Most of students have lost learning opportunities, have learning difficulties and evenly interest in learning because learning can no longer be carried out directly. The application of technology and internet-based learning by online, which is a series of interconnections between technologies that are interconnected with one another or can be called communication via the internet network synchronously or asynchronously as an alternative during the Covid-19 pandemic, is very instrumental in the implementation of learning. Kaizala is included in the learning media that utilizes these two types of communication, namely synchronous and asynchronous media In this case, the author focuses on improving learning outcomes by utilizing technology. Kaizala is an online learning media based on a social media platform that is light to follow such as Whatsapp social media but has the advantage that it is used in learning because it has many supporting features that are suitable for learning. The author conducted Classroom Action Research (CAR) as an effort to improve learning outcomes during the Covid-19 pandemic by using Microsoft Kaizala. Based on the findings in cycle I and cycle II in the description above, it turns out that by applying Microsoft Kaizala learning media by utilizing existing facilities in class XII Accounting 3 students can improve student learning outcomes for Peluang Learning. Keywords: learning outcomes, Covid-19 pandemic, microsoft kaizala 


\section{PENDAHULUAN}

Dari waktu ke waktu pendidikan ikut berkembang sesuai dengan perkembangan zaman. Di abad ke-21 ini, pendidikan menjadi semakin penting untuk menjamin peserta didik memiliki keterampilan belajar dan berinovasi, memiliki keterampilan menggunakan teknologi dan media informasi, serta dapat bekerja dan bertahan dengan menggunakan keterampilan untuk hidup (life skills). Pendidikan abad 21 telah diadaptasi oleh Kementerian Pendidikan dan Kebudayaan Republik Indonesia untuk mengembangkan kurikulum baru untuk Sekolah Dasar (SD), Sekolah Menengah Pertama (SMP), Sekolah Menengah Atas (SMA) dan Sekolah Menengah Kejuruan (SMK). Ada tiga konsep 21 st Century yaitu Skills, scientific approach dan authentic assesment. Selanjutnya, tiga konsep tersebut diadaptasi untuk mengembangkan pendidikan menuju Indonesia Kreatif tahun 2045. Adaptasi dilakukan untuk mencapai kesesuaian konsep dengan kapasitas peserta didik dan kompetensi pendidik dan tenaga kependidikannya.

Memasuki abad ke 21 ini, teknologi berkembang semakin pesat. Sesuatu yang tampaknya mustahil di masa lalu, menjadi sesuatu yang nyata sekarang ini. Contohnya saja komputer, televisi tiga dimensi, gawai, dan lain-lain. Sekarang ini semua alat-alat canggih dapat kita nikmati. . Menurut Rusman, dkk (2012) teknologi berasal dari bahasa Yunani, techne yang berarti 'keahlian' dan logia yang berarti 'pengetahuan'. Dalam pengertian yang sempit, teknologi mengacu pada obyek benda yang digunakan untuk kemudahan aktivitas manusia, seperti mesin, perkakas, atau perangkat keras.

Dalam Surat Edaran (SE Sekretaris Jendral Kementrian Pendidikan dan Kebudayaan No. 15 Tahun 2020 memberikan penjelasan terkait metode dan media yang digunakan dalam Belajar dari Rumah dengan pendekatan dalam metode Pembelajaran Jarak Jauh (PJJ) secara dalam jaringan (daring) dan luar jaringan (luring). Satuan Pendidikan dapat memilih salah satu atau kombinasi dari kedua pendekatan ( Kementrian Pendidikan dan Kebudayaan, 2020). Proses Pembelajaran PJJ daring merupakan metode PJJ yang terdiri dari kegiatan (1) tatap muka virtual dalam bentuk video conferrence, video call, teleconferrence, dan atau diskusi dalam grup di media sosial atau aplikasi pesan instan; (2)menggunakan Learning Management System (LMS)

Suranto (2019) PJJ daring synchronous yaitu interaksi yang berorientasi pada pembelajaran dan difasilitasi dengan instruksi secara langsung, real time, dan biasanya terjadwal . Sedangkan menurut Darmawan (2018) PJJ daring asynchronous dapat diartikan sebagai pembelajaran secara independen dimana peserta didik dapat berinteraksi satu sama lain dengan materi yang telah disediakan pada waktu yang mereka pilih. Kedua model pembelajaran ini sering kali dikombinasikan untuk saling menutupi kekurangan. Menurut penulis bila dilihat dari karakteristik yang telah disebutkan tentang media synchronous dan asynchronous tersebut maka Kaizala termasuk ke dalam media synchronous dan asynchronous dan dapat dijadikan alternatif dalam pembelajaran pada masa pandemi.

Pemaduan penggunaan sumber belajar tradisional (offline) dan online adalah suatu keputusan demokratis untuk menjembatani derasnya arus penyebaran sumber belajar elektronik (e-learning) dan kesulitan melepaskan diri dari pemanfaatan sumber-sumber belajar yang digunakan dalam ruang kelas. Artinya, e-learning bagaimanapun canggihnya teknologi yang digunakan belum mampu menggantikan pelaksanaan pembelajaran tatap muka karena metode interaksi tatap muka konvensional masih jauh lebih efektif dibandingkan pembelajaran online atau $e$ - learning. Selain itu, keterbatasan dalam aksesibilitas Internet, perangkat keras (hardware) dan perangkat lunak (software), serta pembiayaan sering menjadi hambatan dalam memaksimalkan sumber-sumber belajar online (Yaumi, 2018).

Sedangkan menurut Fieka Nurul Ariefa Proses belajar dari rumah melalui pendidikan jarak jauh merupakan solusi yang dalam pelaksanaannya belum optimal secara keseluruhan. Terdapat berbagai hambatan, baik dari sisi sumber daya manusia, pengaturan penyelenggaraan, kurikulum, maupun sarana belajar ( Ariefa, 2020).

Penerapan pembelajaran online dengan kaizala di SMKN 2 Karawang yang diterapkan penulis sejak awal Pandemi Covid-19 telah menjadikan peserta didik lebih mandiri belajar dan 


\section{Vol. 1 No. 4 Oktober 2021 e-ISSN : 2774-6283 | p-ISSN : 2775-0019}

mendalami materi bahan ajar, karena peserta didik dapat belajar kapan saja dan di mana saja, baik secara online maupun offline dan media pembelajaran Kaizala merupakan sosial media yang mudah dipahami dan akrab seperti media whatsapp. Evaluasi pembelajaran dilakukan oleh guru secara otomatis melalui proses digital, sehingga tidak perlu pengoreksian secara manual melalui kertas. Hasil evaluasi yang diperoleh pun akan lebih cepat, akurat dan objektif. Namun sebagai konsekuensinya peserta didik dan pendidik harus melaksanakan transisi cepat ke pembelajaran online, banyak pendidik telah belajar menggunakan alat dan platform online baru, menciptakan cara baru untuk menyampaikan pembelajaran, dan mengalihkan fokus mereka dalam penilaian dari proses evaluatif ke proses yang berpusat pada peningkatan kualitas belajar peserta didik.

Pada penelitian ini penulis mengangkat judul penelitian "Upaya Meningkatkan Hasil Belajar dengan Pemanfaatan Media Online Microsoft Kaizala untuk Materi Peluang Kelas XII Akuntansi di SMKN 2 Karawang." Dengan adanya perbedaan antar harapan dengan kenyataan berdasarkan observasi awal yang dilakukan di kelas XII Akuntansi 3 SMK Negeri 2 Karawang dijumpai beberapa permasalahan yang terjadi antara lain: (1) sebagian besar guru masih dominan menggunakan metode Whatsap dalam pembelajaran daring. Hal ini disebabkan karena masih minimnya pemahaman guru terhadap media pembelajaran online; (2) komunikasi dalam pembelajaran cenderung hanya satu arah yaitu dari guru ke siswa saja, sehingga siswa tidak dilibatkan secara aktif dalam pembelajaran bahkan cenderung hanya menjadi pendengar (aktivitas dan kreativitas siswa dalam pembelajaran masih rendah); (3) motivasi dan minat belajar siswa kurang karena belajar hanya sekedar untuk mendapatkan nilai raport serta kurangnya pemahaman siswa terhadap tujuan pendidikan; (4) persentase ketuntasan belajar dan hasil belajar siswa relatif masih rendah mencapai rata-rata 65, sedangkan Kriteria ketuntasan minimal adalah 73. Selain hal tersebut ditemui pula secara umum peserta didik SMKN 2 Karawang kendalanya adalah karena masih banyak peserta didik yang belum konsisten dalam melaksanakan pembelajaran online karena terkendala penggunaan data seluler baik itu karena biaya tambahan yang harus mereka keluarkan atau terkendala sinyal yang belum merata untuk beberapa tempat yang menghambat proses pembelajaran sehingga hal ini berpengaruh terhadap masih rendahnya hasil belajar yang peserta didik peroleh.

\section{METODE PENELITIAN}

Penelitian ini dilaksanakan di SMKN 2 Kabupaten Karawang. Instrumen yang digunakan dalam penelitian ini adalah tes hasil belajar bentuk uraian yang akan digunakan untuk mengukur hasil belajar siswa berupa soal uraian. Hasil tes akhir tersebut dianalisis statistik untuk nilai rata-rata kelas, daya serap, dan ketuntasan klasikalnya dengan nilai KKM 73. Sedangkan lembar observasi berisi indikator-indikator perilaku siswa seperti 1) antusias dalam mengikuti kegiatan pembelajaran, 2) interaksi antara siswa dengan guru, 3) interaksi antara siswa dengan siswa, 4) kerjasama dalam kelompok, 5) aktivitas siswa dalam diskusi kelompok, dan 6) partisipasi siswa dalam menyimpulkan materi pelajaran.

Penelitian ini merupakan penelitian tindakan kelas (Classroom Action Research). Menurut Suharsimi Arikunto (2014) mengemukakan bahwa dalam penelitian tidakan kelas pada umumnya rancangan setiap siklus terdiri-dari empat tahapan yaitu: a) perencanaan, b) pelaksanaan, c) observasi/pengamatan dan d) refleksi.

Penelitian Tindakan Kelas (PTK), dilakukan dalam beberapa siklus, setiap siklus terdiri dari 4 tahapan digambarkan sebagai berikut. 


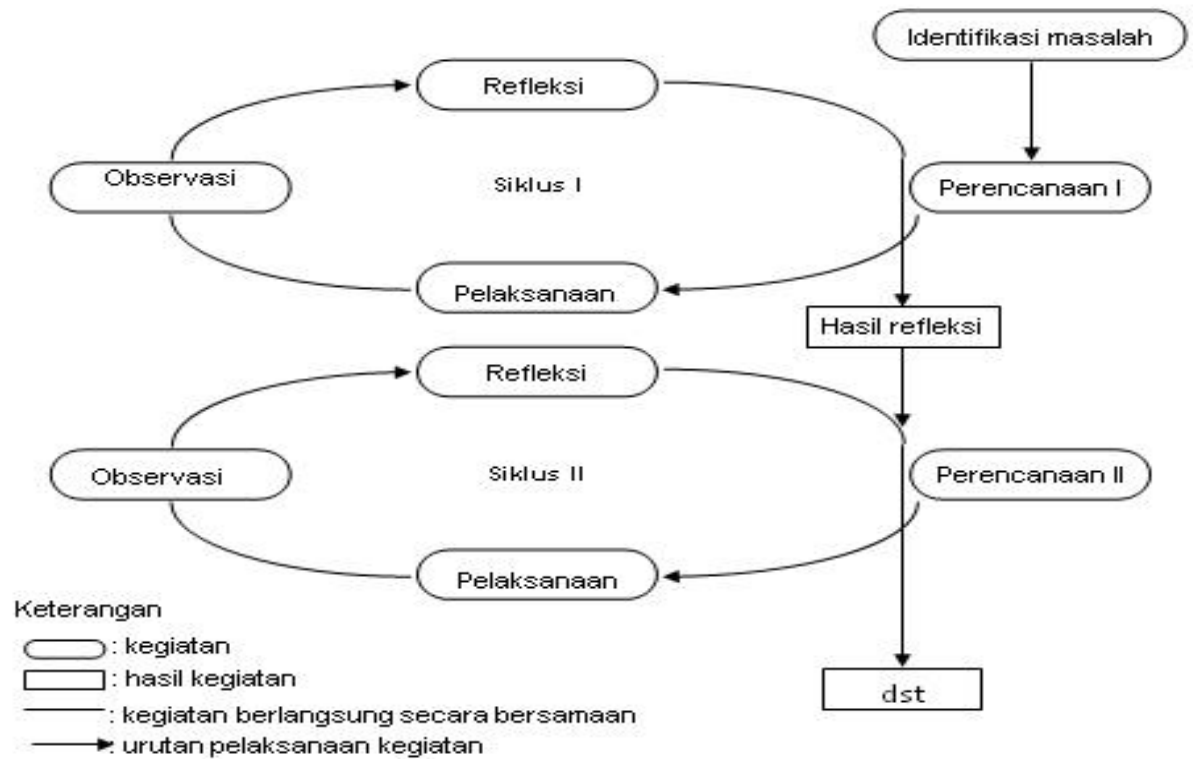

\section{Gambar 1. Siklus Penelitian Tindakan Kelas}

Berdasarkan gambar Siklus Penelitian tindakan Kelas tersebut

a) Perencanaan Tindakan

Beberapa kegiatan yang dilakukan peneliti terkait dengan perencanaan tindakan adalah sebagai berikut.

1) Menyusun permohonan ijin untuk melaksanakan penelitian

2) Menyusun jadwal penelitian.

3) Mempersiapkan silabus dan Rencana Pelaksanaan Pembelajaran.

4) Menyiapkan materi ajar yang diberikan pada setiap kelompok.

5) Menetapkan kelompok heterogen dengan anggota 4-5 orang.

6) Menyusun soal tes akhir siklus I.

7) Melaksanakan penginstalan Microsoft Kaizala pada gawai perta didik

8) Membentuk grup kelas Kaizala

\section{b) Pelaksanaan Tindakan}

Pada tahap ini, peneliti membagikan semua materi ajar, penugasan, serta tes secara online baik tugas individu maupun tugas kelompok dengan memakai fitur-fitur yang ada di aplikasi microsoft kaizala dan penugasan disimpan dalam gdrive.

Pelaksanaan absen melalui Kaizala dalam bentuk memberikan komentar pada pengumuman atau membagikan link absen pada setiap pertemuan pembelajaran secara dalam jaringan/ daring/ online.

Pelaksanaan pembelajaran dalam hal pemberian materi, penugasan individu dan kelompok tidak dibatasi waktu namun hal ini menjadi observasi atas tingkat respon peserta didik dalam pembelajaran. Untuk pelaksanaan tes diberikan penilaian atas waktu pengerjaan dan keseriusan siswa dalam mengerjakan tes dan penugasan.

\section{c) Observasi/Pengamatan}

Kegiatan observasi dilaksanakan oleh peneliti dibantu observer dari kegiatan pembelajaran online melaui grup kelas. Pada kegiatan observasi ini dilakukan pencatatan-pencatatan yang berkenaan dengan: (1) aktivitas guru dan siswa selama pelaksanaan siklus I; (2) kendala-kendala yang dijumpai selama pelaksanaan siklus; (3) kemajuan-kemajuan yang dicapai saat pelaksanaan 


\section{Vol. 1 No. 4 Oktober 2021 e-ISSN : 2774-6283 | p-ISSN : 2775-0019}

siklus; (4) hal-hal lain yang berkenaan dengan dampak yang mungkin ditimbulkan oleh pelaksanaan tindakan. Hasil pengamatan/observasi akan dituangkan dalam bentuk catatan harian, sebagai bahan untuk merumuskan refleksi.

CATATAN HARIAN

\begin{tabular}{|c|c|c|c|}
\hline No. & Pertemuan ke & Uraian & Keterangan \\
\hline 1. & $\ldots \ldots \ldots \ldots$ & $\ldots \ldots \ldots .$. & $\ldots \ldots \ldots \ldots$ \\
2. & $\ldots \ldots \ldots \ldots .$. & $\ldots \ldots \ldots \ldots$ & $\ldots \ldots \ldots \ldots$ \\
3. & $\ldots \ldots \ldots \ldots$ & $\ldots \ldots \ldots .$. & $\ldots \ldots \ldots \ldots$ \\
\hline
\end{tabular}

Tabel. 3.3. Catatan Harian

d) Refleksi

Kegiatan refleksi didasarkan pada hasil observasi/pengamatan yang telah dicatat dalam catatan harian selama proses pembelajaran. Pada tahap ini guru/peneliti mengkaji kekurangan-kekurangan dan hambatan-hambatan yang dialami serta mempertahankan kemajuan-kemajuan yang dicapai dari tindakan yang pada dilakukan untuk bahan pertimbangan pada perancangan dalam pelaksanaan tindakan pada siklus kedua.

Guru memberikan juga link refleksi materi pembelajaran bagi peserta didik sehingga bisa membantu memberikan informasi kepada guru tentang tingkat penguasaan dan pemahaman materi bagi peserta didik dari apa yang guru berikan dalam proses pembelajaran.

\section{HASIL DAN PEMBAHASAN}

\section{Hasil}

Berdasarkan hasil penelitian maka kegiatan pembelajaran dalam jaringan ini penggunaan microsoft kaizala sebagai aplikasi pesan aman dan merupakan aplikasi yang juga simpel dan mudah penggunaannya namun kaya akan fitur yang kita perlukan untuk pembelajaran dalam jaringan (daring/ online) dapat diterima siswa dengan baik dan nyusias. Whatsapp menempati urutan tertinggi penggunaan untuk pembelajaran dalam jaringan (daring/ online) karena memang sudah tidak asing lagi dan familiar dalam kehidupan sehari-hari. tetapi untuk pembelajaran Microsoft Kaizala dari Microsoft Office 365 for Education merupakan aplikasi perpesanan yang tak beda jauh dengan Whatsapp. Memiliki tampilan lembut dan nyaman dengan fitur-fitur yang dapat kita manfaatkan untuk kegiatan pembelajaran jarak jauh dan memiliki banyak kelebihan untuk pembelajaran diantaranya menyediakan fitur komentar dan like pada setiap fitur yang disediakan sesuai fungsinya masing-masing-masing sehingga memiliki kelebihan dari fitur chat biasa karena interaksi chat dapat dilakukan tanpa menenggelamkan chat penting sebelumnya karena siswa bisa chat untuk berdiskusi topik tertentu misalnya dari fitur komentar yang disediakan dalam Kaizala, Fitur pelatihan digunakan guru untuk membuat soal-soal pilihan ganda dan siswa langsung mengerjakan dari HP nya serta hasilnya dapat dilihat langsung. Selain itu guru dapat memberikan soal melalui fitur survey untuk membuat pertanyaan sederhana baik berupa pilihan maupun pertanyaan terbuka dengan jawaban bebas. Fitur pengumuman digunakan guru ketika menyapa siswa dalam kegiatan pendahuluan, memberikan motivasi dan appersepi, serta respons siswa sebagai penanda daftar kehadiran siswa sesuai namanya maka fitur ini berguna untuk membuat pengumuman penting di group kelas. Fitur tugas untuk membagikan tugas kepada anggota group dan melacak status penyelesaiannya. Fitur kuis, kita juga dapat membuat kuis-kuis menarik untuk menambah wawasan dan pengetahuan siswa. Dalam kegiatan pembelajaran kita perlu memberi motivasi dan semangat kepada siswa. Jika dalam tatap muka kita dapat memberikan acungan jempol untuk siswa, di Kaizala kita dapat memanfaatkan fitur kudos untuk memberi semangat kepada siswa serta Fitur $Q \& A$ (Question and Answer) dapat kita manfaatkan untuk diskusi dengan topik tertentu di group kelas agar hasil diskusi tidak tertumpuk dengan chat siswa. 


\section{Vol. 1 No. 4 Oktober 2021 e-ISSN : 2774-6283 | p-ISSN : 2775-0019}

Fitur Game bisa digunakan untuk hiburan siswa ketika pelajaran sudah selesai dalam pembelajaran kita kenal istilah ice breaking. Fitur chat dimana kita bisa mengirim pesan, gambar, file, audio, video, dan kontak secara langsung sama seperti fitur aplikasi perpesanan lainnya. Fitur chat with me, yaitu chat dengan diri sendiri misalnya untuk membuat konsep pesan, menyimpan informasi penting, atau menyiapkan soal latihan sebelum di share di group. Fitur ini berfungsi sebagai buku catatan kita.

Berdasarkan analisis hasil tes yang telah dilakukan oleh peneliti selama proses pembelajaran berlangsung dan pengisian angket yang diberikan kepada siswa, rnaka dapat diungkapkan hasil belajar matematika yang meliputi perolehan nilai dan ketuntasan belajar siswa yang diperlihatkan pada tabel 1 .

Tabel 1. Perolehan Nilai dan Ketuntasan Belajar Per Siklus

\begin{tabular}{|c|c|c|c|c|c|c|}
\hline Siklus & $\begin{array}{c}\text { Jumlah } \\
\text { Siswa }\end{array}$ & Tuntas & $\begin{array}{c}\text { Nilai } \\
\text { Terendah }\end{array}$ & $\begin{array}{c}\text { Nilai } \\
\text { Tertinggi }\end{array}$ & $\begin{array}{c}\text { Nilai } \\
\text { Rata-rata }\end{array}$ & $\begin{array}{c}\text { Ketuntasan } \\
\text { belajar }\end{array}$ \\
\hline I & 36 & 14 & 40 & 80 & 66,61 & $38,8 \%$ \\
\hline II & 36 & 29 & 55 & 100 & 80,18 & $86,11 \%$ \\
\hline
\end{tabular}

Berdasarkan tabel 1 hasil belajar Matematika pada Siklus I menunjukkan bahwa dari jumlah 36 siswa terdapat 22 siswa yang mendapat nilai kurang dari 73 atau ketuntasan belajar hanya sebesar 38,8 \%, dan siswa yang mendapat nilai lebih dari KKM adalah 14 siswa dengan nilai rata-rata kelas 66,61, dan nilai terendah 40 dan serta nilai tertinggi 80 .

Berdasarkan tabel 1 hasil belajar Matematika pada Siklus II dari 36 siswa, terdapat 7 siswa yang mendapat nilai kurang dari 73 atau mencapai ketuntasan belajar sebesar $86,11 \%$, dan siswa yang mendapat nilai lebih dari sama dengan 73 adalah 29 siswa dengan nilai ratarata kelas 80,18 dan nilai terendah 55 serta nilai tertinggi 100.

Tabel 1 dapat direpresentasikan oleh grafik 1 berikut :

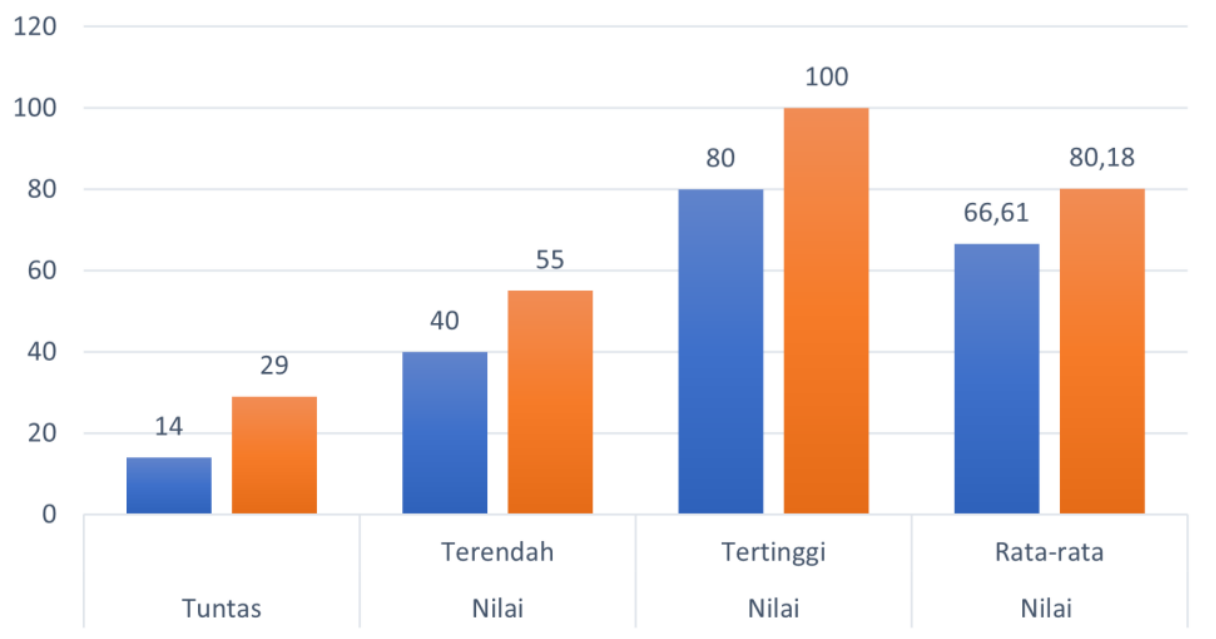

Gambar 2. Grafik Hasil Belajar Matematika pada siklus I dan II

Terlihat dari grafik bahwasanya setiap siklus mengalami peningkatan untuk jumlah siswa yang tuntas yaitu pada siklus I sebanyak 14 siswa meningkat menjadi 29 siswa pada siklus II dengan peningkatan perolehan nilai terendah pada siklus I ke siklus II sebesar 15 dan peningkatan nilai tertinggi pada siklus I ke siklus II sebesar 20 serta peningkatan nilai rata-rata pada siklus I ke siklus II sebesar 13,57

Ketuntasan Belajar Siklus I dan II juga dapat direpresentasikan oleh grafik 2 berikut : 


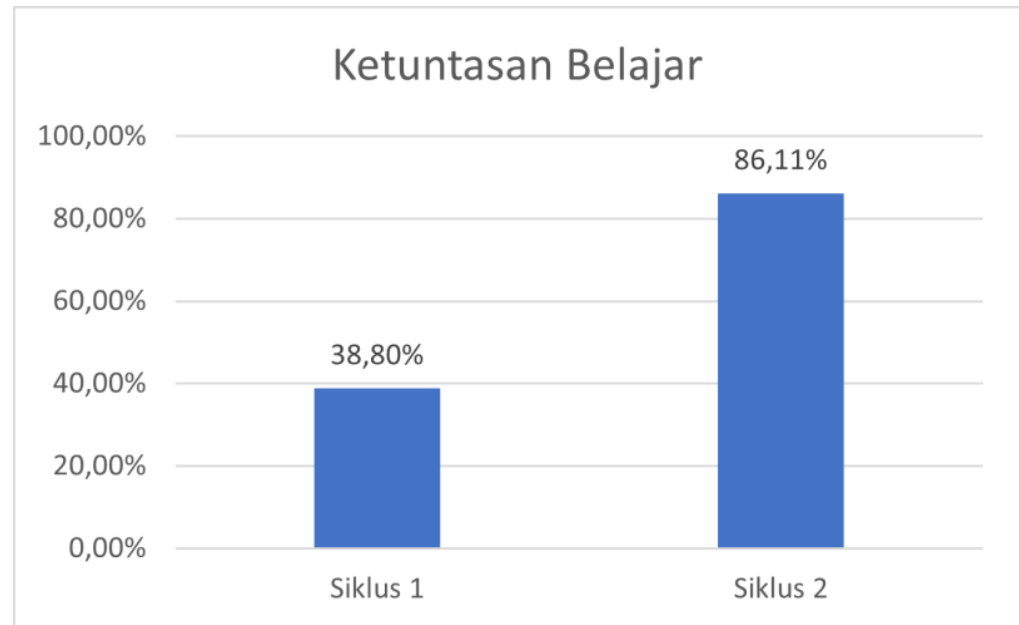

Gambar 3. Grafik Ketuntasan Belajar

Terlihat jelas dari grafik bahwa ketuntasan belajar siswa sebesar 38,80\% pada siklus I mengalami peningkatan yang tinggi sebesar $86,11 \%$ pada saat siklus II sehingga terjadi peningkatan persentase ketuntasan belajar siklus I ke siklus II sebesar 47,31\%.

Hasil analisis kegiatan kelompok belajar siswa dan hasil observasi kegiatan guru pada Siklus I dan II terlihat pada tabel berikut :

Tabel 2. Perolehan Skor Hasil Observasi Siswa dan kegiatan Guru Per Siklus

\begin{tabular}{|c|c|c|c|c|}
\hline Kegiatan & Perolehan skor & Presentase & $\begin{array}{c}\text { Observasi Kegiatan } \\
\text { Guru }\end{array}$ & Presentase \\
\hline Siklus I & 3,28 & $65,6 \%$ & $3,47$. & $65,4 \%$ \\
Siklus II & 3,72 & $74,4 \%$ & 4,00 & $83,6 \%$ \\
\hline
\end{tabular}

Berdasarkan tabel 2, skor kegiatan kelompok belajar siswa pada siklus 1 adalah 3,28 dan hasil observasi kegiatan guru dalam KBM adalah 3,47 sedangkan pada siklus II skor kegiatan kelompok belajar siswa adalah 3,72 dan hasil kegiatan observasi guru dalam KBM adalah 4,00. Jika digambarkan dalam grafik terlihat jelas peningkatan perolehan skor hasil dan observasi kegiatan guru seperti yang ditunjukkan oleh grafik 3 berikut :

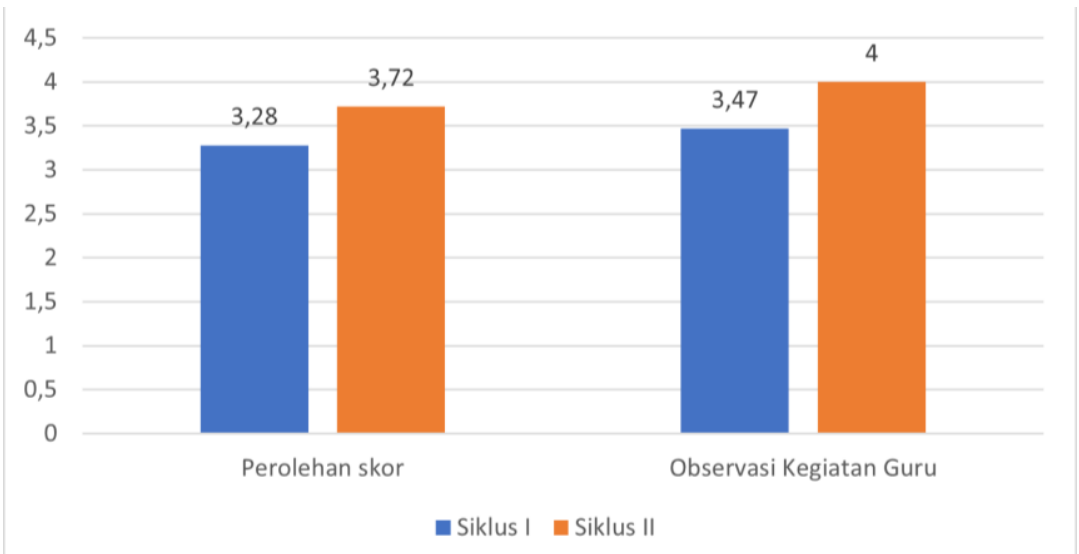

Gambar 4. Grafik Perolehan Skor Hasil Observasi Siswa dan Kegiatan Guru Per Siklus

Dari grafik terlihat bahwasanya skor kegiatan siswa adalah 3,72 dan hasil kegiatan observasi guru dalam KBM adalah 4,00. Jika digambarkan dalam grafik terlihat jelas peningkatan perolehan skor hasil dan observasi kegiatan guru seperti yang ditunjukkan oleh grafik 5 berikut : 


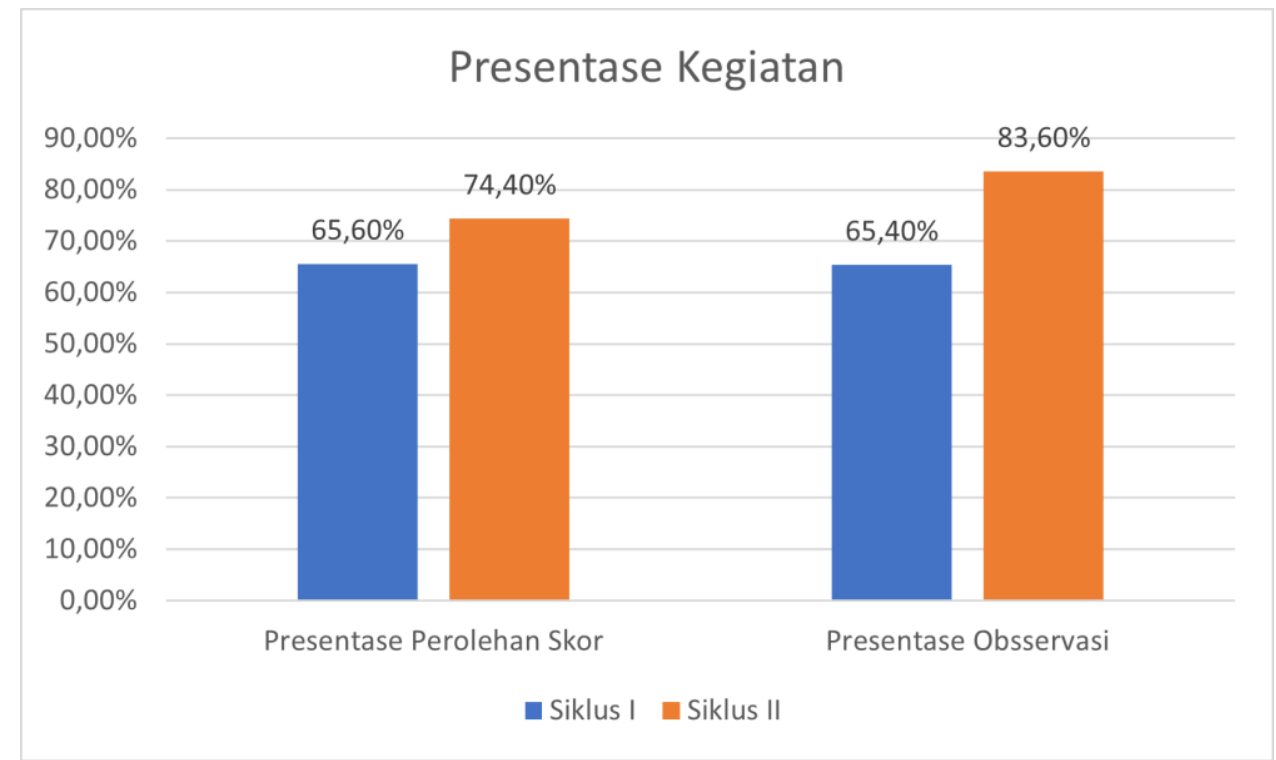

Gambar 5. Grafik Perolehan Skor Hasil Observasi

\section{Pembahasan}

Berdasarkan analisis hasil data penelitian, pada siklus I perolehan hasil pada pembelajaran siklus I dari nilai rata-rata, ketuntasan klasikal, dan hasil observasi siswa dan guru maka siklus I perlu diulang kembali agar hasil belajar siswa kelas XII Akuntansi 3 SMKN 2 Karawang dengan menggunakan Microsoft Kaizala pada materi Peluang lebih meningkat dan ketuntasan belajar siswa dapat tercapai. Setelah melaksanakan pembelajaran siklus II maka nilai rata-rata dan hasil observasi siswa dan guru pada siklus II mengalami peningkatan dan ketuntasan klasikal belajar siswa telah sesuai dengan tujuan yang ingin dicapai maka penelitian hanya sampai pada siklus II sehingga tidak perlu mengulang pembelajaran sampai siklus berikutnya .

Berdasarkan hasil observasi dan refleksi pada siklus II dihasilkan temuan siswa mulai terampil dalam menerapkan media belajar online Microsoft Kaizala. Walaupun masih ada kendala, hal ini disebabkan karena pembelajaran daring atau online memiliki berbagai kendala diantaranya penggunaan kuota internet maupun kondisi sinyal di daerah pengguna. Berdasarkan hasil belajar dan hasil observasi siswa dan obsevasi KBM guru pada akhir siklus II telah mengalami peningkatan dan telah sesuai dengan tujuan yang ingin dicapai maka penelitian hanya sampai pada siklus II.

Berdasarkan refleksi hasil dan pembahasan pada siklus I dan siklus II terdapat temuantemuan sebagai berikut :

1. Proses pembelajaran berlangsung dengan lancar sehingga pembelajaran dapat berjalan sesuai dengan yang diharapkan. Hal ini terbukti dengan adanya peningkatan skor rata-rata hasil observasi guru dari siklus I ke siklus II yang terlihat pada hasil penelitian.

2. Kinerja, semangat dan kerjasama siswa dalam pembelajaran pada siklus I dan siklus II mengalami peningkatan.

3. Siswa mulai terbiasa dengan pola belajar online dan benar-benar memiliki tanggung jawab dalam belajar. Siswa bertambah terampil dan lancar dalam menyampaikan informasi kepada teman dalam kelompoknya masing-masing sehingg skenario pembelajaran dapat berjalan sesuai dengan apa yang diharapkan. Hal ini terbukti dengan adanya peningkatan perolehan skor rata-rata hasil observasi siswa dari siklus I ke siklus II

4. Berdasarkan hasil nilai rata-rata siklus I dan siklus II dan hasil nilai rata-rata siklus II telah terjadi peningkatan nilai rata-rata dan peningkatan ketuntasan klasikal. Dari hasil analisis penelitian siklus I sampai dengan Siklus II maka dapat disimpulkan bahwa pemahaman siswa pada pokok materi Peluang melalui media pembelajaran online Microsoft Kaizala telah mengalami peningkatan. Peningkatan ini dapat dilihat dari perolehan hasil belajar siswa berupa nilai rata-rata, daya serap dan ketuntasan klasikal. 


\section{Vol. 1 No. 4 Oktober 2021 e-ISSN : 2774-6283 | p-ISSN : 2775-0019}

Refleksi tersebut akan lebih bermakna apabila peneliti lain bisa mencoba mengemukakan lebih mendalam tentang pengaruh media pembelajaran Microsoft Kaizala terhadap hasil belajar siswa.

Berdasarkan hasil temuan pada siklus I dan siklus II pada uraian diatas ternyata dengan menerapkan media pembelajaran microsoft kaizala dengan memanfaatkan sarana yang ada pada siswa kelas XII Akuntansi 3 dapat meningkatkan hasil belajar siswa untuk materi Peluang.

Hasil Penelitian Tindakan Kelas dari Kasiyatun (2021) menjelaskan bahwa partisipasi dan prosentase ketuntasan pada bidang study matematika materi peluang suatu kejadian dengan alat peraga di masa pandemi covid-19 melalui google class room (GC) dan WhatsApp Group (WAG) dapat meningkatkan partisipasi dan hasil belajar matematika pada saat Pandemi Covid-19 di SMK Negeri 1 Liwa, Lampung Barat dengan semangat seorang pengajar memegang peranan penting dalam menghadirkan kemampuan literasi siswa dan akses teknologi peserta didik tertentu. dan dapat menjembatani peserta didik dalam penggunaan media informasi seperti halnya google classrom( $G C)$ dan whatshapp $\operatorname{group}(W A G)$.

Hasil penelitian dan pembahasan penulis sejalan dengan hasil penelitian Salma, dkk (2013:105) menjelaskan persiapan sebelum memberikan layanan belajar merupakan salah satu faktor penentu dalam keberhasilan belajar, terutama pada online learning di mana adanya jarak antara pebelajar dan pemelajar. Pada pemberlajaran ini pemelajar harus mengetahui prinsipprinsip belajar dan bagaimana pembelajar belajar. Sedangkan pada penelitian Verawati dan Enny Comalasari yang berjudul "Pemanfaatan Android dalam Dunia Pendidikan" mengungkapkan bahwa adanya dampak android dengan jagat persekolahan di Indonesia saat ini yaitu mulai dari proses pembelajaran berlangsung mengalami kemudahan dalam berkomunikasi, di mana semua materi tersedia di internet dan itu mudah diakses. Diuraikan pula bahwa model e-learning berbasis webcentric course mempunyai pengaruh terhadap perubahan perilaku siswa sehingga menjadi mandiri dan aktif hal ini juga dapat meningkatkan daya ingatan siswa hingga hasil belajarnya.

\section{KESIMPULAN}

Penguasaan konsep peluang pada siswa kelas XII Akuntansi SMKN 2 Karawang dengan menerapkan media belajar online tampak jelas meningkat, terlihat dari hasil belajar dari Siklus I mengalami peningkatan ke siklus II. Media belajar Microsoft Kaizala merupakan suatu media pembelajaran yang mengkondisikan siswa untuk belajar dengan memanfaatkan platform ringan media sosial untuk chatting tetapi memiliki fitur-fitur yang lebih lengkap dari media sosial biasa untuk pembelajaran jarak jauh. Dalam menyelesaikan tugas-tugasnya, setiap siswa baik secara perorangan ataupun sebagai anggota kelompok bekerja sama dan saling membantu untuk saling memahami materi yang diberikan, membantu memberikan informasi kepada teman satu kelompok sehingga dapat meningkatkan hasil belajar.

\section{DAFTAR PUSTAKA}

Arifa, F. N. (2020). Tantangan Pelaksanaan Kebijakan Belajar dari Rumah dalam Masa Darurat Covid-19. Jurnal Kajian Singkat terhadap Isu Aktual dan Strategis. 1(1), 3345.

Arikunto, S. (2014). Penelitian Tindakan Kelas. Jakarta: PT. Bumi Aksara.

Briliannur Dwi C., Aisyah Amelia., Uswatun Hasanah, Abdy Mahesha Putra., Hidayatur Rahman. (2020). Analisis Keefektifan Pembelajaran Online di Masa Pandemi Covid19. Jurnal Pendidikan Guru Sekolah Dasar.

Darmawan, E. (2018). Implementasi Model Pembelajaran Asynchronous Dalam Perancangan Aplikasi Simulasi Panduan Pecinta Alam Berbasis Android. Cloud Information, 3(2)

Fahmi. M. H. Komunikasi Synchronous dan Asynchronous dalam E-learning Pada Masa pandemic Covid-19. Jurnal Nomosleca, Vol. 6 No.2, Oktober 2020. 
Gusty, Sri dkk. (2020). Belajar Mandiri : Pembelajaran Daring di Tengah Pandemi COVID19, Yayasan Kita Menulis.

Kasiyatun. (2021). Peningkatan Partisipasi Hasil Belajar Matematika Peluang Dengan Alat Peraga Di Masa Pandemi Covid-19 Melalui Google Classroom: Jurnal Pendidikan Matematika Volume 2, No. 2, 2021. 114

Kementerian Pendidikan dan Kebudayaan (2020), Pedoman Penyelenggaraan Belajar Dari Rumah Dalam Masa Darurat Penyebaran Corona Virus Disease (Covid-19). Surat Edaran Nomor 15 Tahun2020, pp.1-20

Prawiradilaga, Salma, dkk. (2016). Mozaik Teknologi Pendidikan : E- Learning. Jakarta : Prenadamedia Group.

Rusman dkk. (2012). Pembelajaran Berbasis Teknologi Informasi dan Komunikasi. Jakarta : Grafindo Persada.

Rusman. (2012). Belajar dan Pembelajaran Berbasis Komputer. Bandung: Alfabeta.

Sadiman AS, dkk. (1990). Media Pendidikan: Pengertian, Pengembangan dan Pemanfaatannya. Jakarta: CV Rajawali.

Suardiman \& Ibrahim. (2014). Pengaruh Penggunaan E-Learning Terhadap Motivasi dan Prestasi Belajar Matematika: Jurnal Prima Edukasia, 2(1), 56-66.

Undang-undang Republik Indonesia Nomor 20. (2003). Tentang Sistem Pendidikan Nasional Jakarta: BP. Cipta Jaya.

Verawati, Enny Comalasari. (2019). Pemanfaatan Android dalam Dunia Pendidikan. Palembang: Universitas PGRI.

Yaumi, Muhammad. (2018). Media Dan Teknologi Pembelajaran. Jakarta : Prenadamedia Group. 